\title{
FACTORS AFFECTING INVESTOR DECISIONS TO INVEST IN STARTUP: A CASE STUDY OF STARTUP XYZ
}

\author{
Putri Dwirachmayuni Ch. ${ }^{*}$, Fahmi Idqan, Suroso Arif Imam \\ Business School, Bogor Agricultural University, Indonesia \\ *E-mail: dwirachmayuni@yahoo.com
}

\begin{abstract}
The rapidly growing startup that happened all over the world, including Indonesia, not only caused by technology development and internet invasion but also the investor who participates in taking risk through their funds in this high-risk-high-return industry. The study aims to determine investor perceptions before they decided to invest in a particular startup by used $X Y Z$ company as a study case. The research was conducted by carrying out a depth interview on the internal party (startup $X Y Z$ ) to find out the current conditions and strategies of the company, and external parties (three investors and three startups who have received funding from investors) to get a view on influence investors in investing as well as opinions related to startup $X Y Z$. Data from interview results were processed using the IPA (Importance-Performance Analysis) method. Twenty-nine indicators are used as a reference to consider whether this affects investors to invest in startups. From the results obtained, it showed that some signs are very influential on investor decisions and some have no effect. The recommended strategies for $X Y Z$ startups are 1) increasing the focus of product development based on indicators considered necessary by investors based on ImportancePerformance Analysis, 2) marketing specific market segments, 3) cooperating with certification bodies for customers who already passed Al Quran reading through the Learn Tajwid application.
\end{abstract}

\section{KEY WORDS}

Startup, investor, importance performance analysis, management strategy.

$X Y Z$ is an Indonesian startup base that provides digital education to learn to read Quran, called Learn Tajwid Application. XYZ sees some challenges for Muslim people who live in a Muslim minority country in learning to read Quran with Tajwid (proper rules of recitation), such as hard to find teacher, the busy schedule, or the long distance to reach the Islamic Centre. Learn Tajwid, that made in 2015, designed with visual and audiovisual who voiced directly by Qori (a person who recites the Quran with the proper Tajwid) who experienced in international Quran recitations and lecturers of various Quran classes. Learn Tajwid has a high standard learning curriculum compiled by an instructor from LIPIA (Islamic and Arabic Science Institutions). Currently, Learn Tajwid depends on ads in application and premium subscriber as their business model.

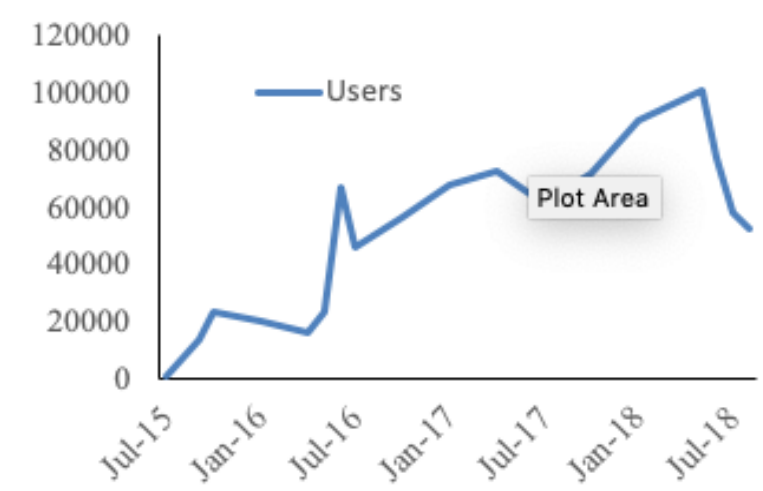

Figure 1 - Learn Tajwid Monthly Active Users period July 2015 to August 2018 
Learn Tajwid have more than 1,5 million registered users, with around 60 thousand monthly active users as shown in Figure 1. In 2017, Learn Tajwid selected by ummahwide.com as one of the 21 most innovative global Muslim apps of 2017 . This achievement is undoubtedly proud of local startups from Indonesia that can compete globally in their two years old.

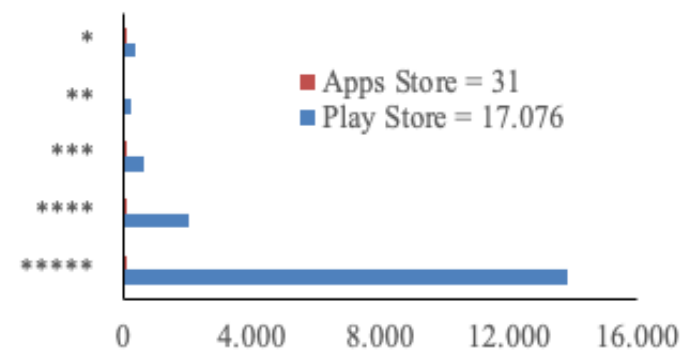

Figure 2 - Learn Tajwid Rate in Android and IOS

Learn Tajwid mostly accessed from Android phone than IOS; the application got the highest rate in Play Store (five stars ${ }^{* * * *}$ ) by 13,806 users as shown in Figure 2.

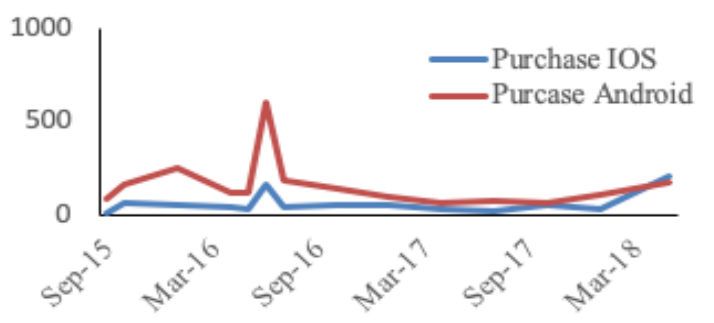

Figure 3 - The total purchased of Learn Tajwid in IOS and Android for period of September 2015 to May 2018

Unfortunately, of all the achievement above, the total purchased of premium subscriber Learn Tajwid as shown in Figure 3, it is less than $10 \%$ from the Monthly Active Users. It indicated that XYZ would get around USD \$200-300 per month from this income segment which is quite low. Combined with ads that projected to reach around USD $\$ 11.000$ from May 2016 until June 2018 (based on data from XYZ), XYZ will be expected to get revenue USD $\$ 5.000$ per month or USD $\$ 60.000$ annually. This amount is not enough to pay company operational cost and further product development. Currently, the company have another income source from donations.

Due to this condition, $X Y Z$ CEO decided to open opportunities for investors to fund the business. And understanding about investor preferences in startup investing will be necessary for the management. Before that, startup $X Y Z$ have to make sure; What indicators' that attract investor to invest in startup? And what investor perception about startup XYZ?

\section{LITERATURE REVIEW}

Warner (2011) and Graham (2012) defined a startup as an early stage company which has a product or service that are attractive, innovative, solutions and can meet the customer needs. The startup also designed with the aim of the company that able to rapid growth. According to Blank (2018), a startup is a temporary organization that developed to find business models that are repeatable and scalable. The differences between startups with another small business is that startup developed to create new and innovative services or products in conditions of high uncertainty. People who dare to make new products or services in an uncertain situation are entrepreneurs, regardless of whether they work alone, for-profit companies, or non-profit organizations' (Ries 2011). 
Investment is the placement of one or several existing funds with hope that the investor(s) will generate profits, either from dividend or selling the stock with higher value in the future. In investing, investors need information from indicators that are considered important as a reference for deciding whether to invest or not (Halim 2005; Christanti et al. 2011). According to Goudriaan (2016), there are several types of investors for a private firm: Angel Investor, Venture Capital and Private Equity. Angel Investor is someone who use personal funds to invest in a startup that they think has a promising prospect. One example of the angel investor association in Indonesia is Indonesia Angel Investment Network (ANGIN)). Venture Capital is a firm that collects funds from several investors to invest in a particular business that considered to have long-term growth and profit potential (Muliya \& Imaniyati 2008; Buchari et al. 2016)). Private Equity is a company that collects funds from limited parties to invest in strategic investment instruments with long periods.

Ghosh (2012) researched 2,000 startups that had been funded by venture capital from 2004 to 2010 . The study concluded that $75 \%$ of the total startups studied never returned money or provided benefits to investors. Furthermore, based on research conducted by CB Insight (2018), there are five reasons that make startup fail: making unnecessary products $(42 \%)$, empty cash $(29 \%)$, lousy team management $(23 \%)$, losing competition in the market (19\%), and price selection inappropriate product (18\%). Therefore, choosing the right method in the business model translation is a very crucial moment for a startup to reduce the risk of failure. The vision and strategy at startup are vital, and the right use of business models can make it easier for startups to create strategies to achieve the company's mission.

According to Muzyka (1996) quote by Nunes et al. (2014), there are 45 criteria used by Venture Capital in selecting and evaluating a startup. These criteria have been categorized into six categories. The first category is the personality of the entrepreneur: capacity of reaction and risk assessment, ability to perform a continuous and intense effort, desire to earn money, honesty and integrity, attention to detail, favorable to suggestions and critics, long-term vision, and ability to raise empathy with the VCs. The second category is the experience of the entrepreneur and management team: educational record, ability to organize the management team, professional experience, knowledge of the sector, focused and familiar with the market objectives of the company, entrepreneur available capital, references of others, technical skills, and management skills. The third segment is market: market size, the growth rate of the target market, VCs familiar with product market, company ability to create a new market to the product or service, minimum competition in the first three years, barriers to entry of new products, and easy access to distribution channels and suppliers. The fourth category is product or service: company owning the patent, product with demonstrated market acceptance, the product developed to the point of a prototype, hightech product, potential foreign market, uniqueness of product, availability of raw materials, and innovation in the production process. The fifth category is financial aspects: expected rate of return, structure costs, time to break-even, time to pay back, investment size, synergy with current investees of the VCs, capacity to obtain complementary financing, and ease of exit. The last category is other investment aspects such as geographic location, business plan quality, VCs intuition, sensibility to economic cycles, production capacity.

\section{METHODS OF RESEARCH}

This research collects premier and secondary data. The premier data used in this research was 29 indicators that represent nine elements that exist in the business model, product and strategies. These elements are obtained through in-depth interview with the founder of $X Y Z$, startup investor, and startup enthusiast. On the other hand, secondary data are procured from scientific literature and online news. Data was collected since June 2018 until February 2019.

Importance-Performance Analysis (IPA) was first introduced by Martilla and James in 1977, where they used it to measure the importance and attributes of performance about customer satisfaction with the services provided when offering car sales services. The IPA method is used to measure the performance of satisfaction that is considered important by 
the customer and the satisfaction performance received by the customer (Algifari 2016). The IPA method is a method that is easy to implement, cost-effective, and can easily evaluate the effectiveness of marketing programs (Wong 2015).

The operational variable is a complete set of instructions on what must be observed and measuring something or concept to test perfection. Operational definitions of variables are needed to explain variables that have been defined as efforts to understand in this study, the following variables that are thought to be the considerations of respondents in investing in startups based on the journal Nunes et al. (2014), other related journals and input from investors. The researcher found that there are 29 indicators considered as essential and used by investors in evaluating companies according to Muzyka et al. (1996). The indicator is divided into three parts, as 1 . Individual Perspective, consists of Product affinity, Work ethics at the company, Corporate responsibility to the environment, Charisma from company leaders, Vision mission founder, Work experience / entrepreneurial experience at the founder, Number of founders, Company legality, Growth of the company, Core team, Acquisition level, Timing is appropriate, Product concept, and Solving problem; 2. Fundamental Market consists of Revenue / profit, future projects, company cash flow, market size, previous investment, attraction, corporate sustainability, company valuation, and exit options; 3. The Public Perspective consists of: Comments from experts on the media, Number of advertisements on TV / radio / internet / etc., company decisions to follow government regulations, public sentiment towards companies, competitors, and market/industry conditions. Based on the indicators above, researchers obtained results from questionnaires distributed to respondents who had been selected based on purposive sampling from six respondents consisting of venture capital, angel investors and startup founders

This research used descriptive quantity analysis introduced by Miles and Huberman (1984) with management strategy concepts approach obtained from scientific literature and purposive sampling from respondents' opinions. Furthermore, Importance-Performance Analysis (IPA) Martilla and James (1977) has been selected as the primary tool to identify key attributes of performance that playing an important role in customer satisfaction.

Likert Scale measurement was used to give clarity of the level of importance which the lowest intensity scored as one (not important), and the highest intensity scored as five (the most important). For the level of performance, the lowest intensity recorded with one (not satisfied at all) while the highest intensity recorded with five (very satisfy). These scales will be placed in the Importance-Performance Matrix. This matrix as shown in Figure 4, is consisting of four quadrants: 1. Concentrate Here, 2. Keep Up the Good Work, 3. Low Priority, 4. Possibly Overkill. The interpretations of the quadrant are as follows (Martilla and James 1977; Wong 2015):

1. Concentrate Here. Quadrant one shows that the indicators in this quadrant are crucial for the customer but the performance or service provided is not satisfactory or the quality of service is poor. Therefore, the indicators included in quadrant 1 are the top priority for improvement.

2. Keep Up the Good Work. The second quadrant shows that the indicators in this quadrant are considered important by the customer and the performance or service provided is satisfactory, or the quality of service is excellent. No changes are needed in this quadrant, other than to maintain consistency in performance or service.

3. Low Priority. The third quadrant shows that the indicators included in this quadrant are considered to have a low or less important level of importance by the customer and the level of performance or service provided is of low quality. So that resources allocated to attributes in this quadrant may need to be reviewed and reduced.

4. Excessive (Possibly Overkill). In quadrant 4, the indicators included in this quadrant are considered not important by the customer, but the performance or services provided by the company are of good quality. Therefore, the indicators included in this quadrant are considered excessive, and the resources allocated to this quadrant must be reviewed, reduced or stopped by the product or service, and the resources transferred to other attributes so that the performance is optimal and efficient for the company. 


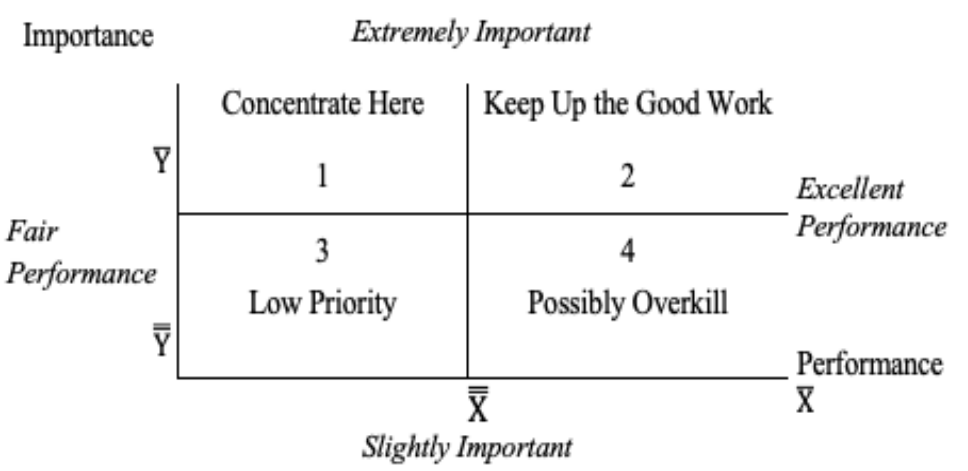

Figure 4 - The Importance-Performance Matrix

The measurement to calculate the score in this research are:

$$
\bar{X}_{i}=\frac{\sum_{i=1}^{n} X_{i}}{n} \quad \bar{Y}_{i}=\frac{\sum_{i=1}^{n} Y_{i}}{n}
$$

1. Calculation of the average level of importance and performance for each item of the attribute: with $\mathrm{Xi}$ is score of the average performance level of the $i$ attribute, $Y i$ is score of the average level of importance of the $i$ attribute and $n$ is the number of respondents.

$$
\overline{\bar{X}}=\frac{\sum_{i=1}^{p} \bar{X}_{i}}{p} \quad \overline{\bar{Y}}=\frac{\sum_{i=1}^{p} \bar{Y}_{i}}{p}
$$

2. Calculation of the average level of interest and performance for the overall attribute:

With $\mathrm{X}$ is an average level of performance, $\mathrm{Y}$ is a value of average level of importance, and $P$ is the number of attributes.

\section{RESULTS AND DISCUSSION}

Kaplan and Lerner (2010), prove that almost half of the companies listed on the Stock Market (IPO) are companies that have been funded by Venture Capital. Furthermore, Harris, Jenkinson and Kaplan $(2014,2016)$ found that the average startup that had been financed by investors had an outstanding performance in the Stock Market. And the result after calculating the Importance-Performance Analysis formula from the 29 indicators as shown in Table 1.

As shown in Table 1, the average value obtained from the respondents' interest in the startup of $\mathrm{XYZ}$ according to respondents is 4.0 . This shows that the indicators that are considered by investors to invest in startup are those which values are above the average value of 4.0, namely: Vision and mission of the founder (5), Sustainability (4.8), Product concept (4.7), Market size (4.7), Charisma of the company leader (4.5), Company growth (4.5), Future projects (4.5), Work ethics at the company (4.3), Appropriate timings (4.3), Solving problem (4.3), Number of advertisements on TV / radio / internet / etc. (4.3), Product affinity (4.2), Acquisition level (4.2), Revenue / profit (4, 2), Market / industry conditions (4.2), Core team (4.0), and Attraction (4.0).

While indicators which values are below the average value, are indicators that are not too considered by investors to invest such as: Corporate valuation (3.8), Exit Options (3.8), Comments from experts on the media $(3,8)$, Community sentiment towards the company $(3,8)$, Competitors $(3,8)$, Corporate responsibility in the environment $(3,7)$, Work experience / entrepreneurial experience at founder $(3,5)$, Company legality $(3,3)$, Company cash flow (3.2), following government regulations (3.2), previous investment (3), and number of founders $(2,3)$. 
Table 1 - Average Value of Importance and Average of Performance from XYZ

\begin{tabular}{|c|c|c|c|}
\hline No. & Factors & $\begin{array}{l}\text { Average } \\
\text { Importance }\end{array}$ & $\begin{array}{l}\text { Average } \\
\text { Performance }\end{array}$ \\
\hline & Individual Perspective & & \\
\hline 1 & Product affinity & 4,2 & 4 \\
\hline 2 & Work ethics at the company & 4,3 & 3,7 \\
\hline 3 & Corporate responsibility for the environment & 3,7 & 3,7 \\
\hline 4 & Charisma from the company leader & 4,5 & 4,5 \\
\hline 5 & Founder's mission vision & 5 & 4,8 \\
\hline 6 & Entrepreneurial experience / work experience at the & 3,5 & 3,7 \\
\hline 7 & Number of founders & 2,3 & 2,7 \\
\hline 8 & The legality of the company & 3,3 & 3,5 \\
\hline 9 & Company growth & 4,5 & 4,3 \\
\hline 10 & Core team & 4 & 4,7 \\
\hline 11 & Acquisition level & 4,2 & 4 \\
\hline 12 & Appropriate timings & 4,3 & 4,5 \\
\hline 13 & Product concept & 4,7 & 4,8 \\
\hline 14 & $\begin{array}{l}\text { Solving problem } \\
\text { Fundamental Market }\end{array}$ & 4,3 & 4,5 \\
\hline 15 & Revenue / profit & 4,2 & 4,2 \\
\hline 16 & Future projects & 4,5 & 4,3 \\
\hline 17 & Company cash flow & 3,2 & 3,5 \\
\hline 18 & Market size & 4,7 & 4,7 \\
\hline 19 & Previous investment & 3 & 3 \\
\hline 20 & Attraction & 4 & 4,3 \\
\hline 21 & Sustainability of the company & 4,8 & 4,7 \\
\hline 22 & Company valuation & 3,8 & 3,8 \\
\hline \multirow[t]{2}{*}{23} & Exit Options & 3,8 & 4,2 \\
\hline & Public Perspective & & \\
\hline 24 & Comments from experts on the media & 3,8 & 3,7 \\
\hline 25 & Number of advertisements on TV / radio / internet / etc. & 4,3 & 4 \\
\hline 26 & The company's decision to follow government regulations & 3,2 & 3,3 \\
\hline 27 & Community sentiment towards the company & 3,8 & 4 \\
\hline 28 & Competitor & 3,8 & 3,7 \\
\hline \multirow[t]{2}{*}{29} & Market / industrial conditions & 4,2 & \\
\hline & Average & 4,0 & 4,02 \\
\hline
\end{tabular}

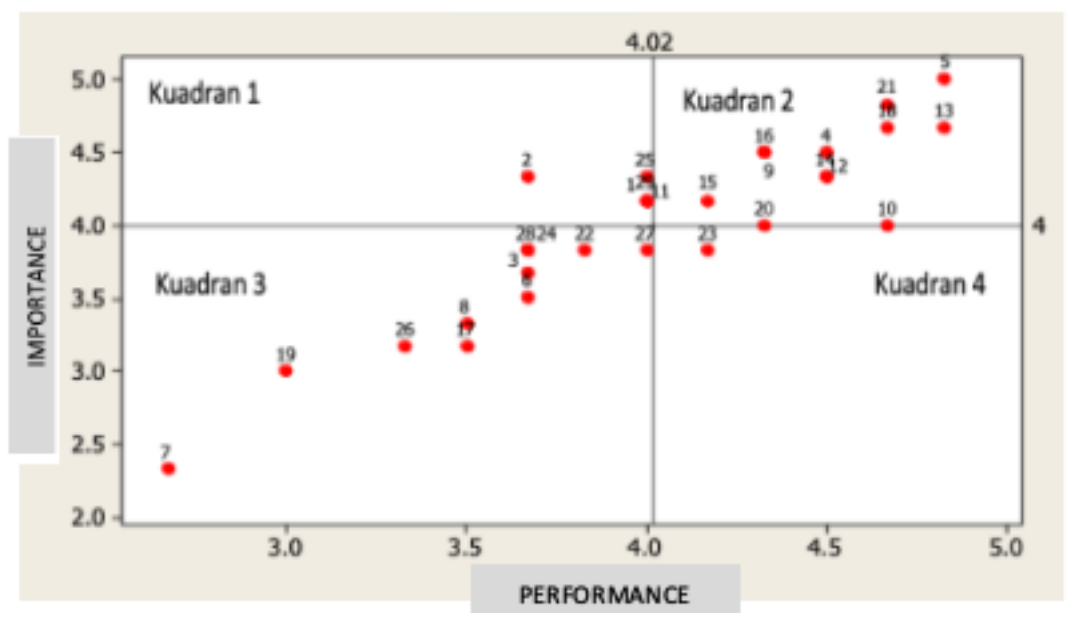

Figure 5 - Importance-Performance Matrix with 29 Indicators

Based on Table 1, the average value obtained from respondents' performance on startup $X Y Z$ is 4.2 and the indicators that influence investors' perceptions of startup $X Y Z$ are indicators which values are above the average value of 4.2 , namely: Vision of the founder (4.8), Product concept (4.8), Core team (4.7), Market size (4.7), Sustainability of the company (4.7), Charisma of the company leader (4.5), Appropriate timing (4.5), Solving problem (4.5), Corporate growth (4.3), future projects (4.3), Attraction (4.3), Revenue / profit (4.2), and Exit Options (4.2). 
While indicators which values are below the average value, are indicators that do not affect investors' perceptions of investing in startups, namely: Product Affinity (4.0), Acquisition level (4.0), Number of advertisements on TV / radio / internet / etc. (4.0), community sentiment towards the company (4.0), market / industry conditions (4.0), company valuation (3.8), work ethics in the company (3.7), corporate responsibility in the environment (3.7), Entrepreneurship experience at founder (3,7), Comments from experts on media $(3,7)$, Competitors $(3,7)$, Company legality $(3,5)$, Cash flow company $(3,5)$, Company decisions to follow government regulations (3.3), previous investment (3.0), and number of founders (2.7).

The data used to perform IPA calculations are data obtained from the results of depth interviews with questionnaires and carried out by purposive sampling with respondents who have been determined, namely representatives of BUMN (State-Owned Enterprise) and private Venture Capital, Angel Investors and Startup Activists. From the interviews, the results are included in a graph that shows an assessment of current interests and conditions. These results are plotted into the Importance-Performance Matrix as shown in Figure 5.

From Figure 5, it can be seen that the 29 indicators that allegedly influence investors' decisions to invest in startups are as follows:

In Figure 5, there is Importance-Performance Matrix that illustrates the spread of 29 indicators to 4 quadrants and indicators that are the main priorities to be addressed by startup $\mathrm{XYZ}$ in the first quadrant as in Table 2.

Table 2 - The Main Priorities that must be addressed at Startup XYZ

\begin{tabular}{ll}
\hline No & Attribute \\
\hline 2 & Work ethics at the company \\
25 & Number of advertisements on TV / radio / internet / etc. \\
1 & Product affinity \\
11 & The level of acquisition offered \\
29 & Market / industrial conditions \\
\hline
\end{tabular}

As seen on Table 2, there are 5 main priorities that must be addressed at startup $X Y Z$ such as: 1 . Work ethics at the company, it can indicate that ethics is the science of what is good and bad, and about moral rights and obligations. It can be concluded that work ethics is a value system adopted by someone, such as relationships between employees and companies. And the respondents considered the performance of ethics in XYZ still not in line with the expectations and judged to be able to hinder the development of the company. 2 . Number of advertisements on TV / radio / internet / etc. are indicated that the marketing campaign strategy carried out by XYZ. Respondents considered the lack of marketing campaigns strategy which resulted in users being less familiar with Learn Tajwid, so the expected targets were still not achieved. 3. Product affinity is an interest characterized by equality of interests. In the business world, it is known as affinity marketing or strategic partnership between complementary brands that sell similar products. Respondents considered that the product affinity of Learn Tajwid was quite appropriate, but in a strategic partnership XYZ had not been able to meet respondents' expectations with their current performance. 4. The level of acquisition offered by the company greatly influences investors' decisions to invest in the company or not. Because it affects what percentage of acquisition the investor can have and how much the funds will be distributed to the company. Respondents considered that the current level of acquisition offered by XYZ (performance) was not interesting, therefore the strategy needed to be re-established. 5. Market / industrial conditions be considered by investors before deciding to invest or not, because it affects the return that investors will get in the future. According to respondents, the digital education market conditions are very promising. But this is needed to be proven by $\mathrm{XYZ}$ by showing how much market share is currently owned.

$X Y Z$ is good enough in the eyes of respondents; this can be seen from 29 existing indicators; there are 12 of indicators whose achievements should be maintained by $X Y Z$. These indicators are attributes that are included in the second quadrant as in Table 3. 
Table 3 - Achievements that should be maintained by XYZ

\begin{tabular}{ll}
\hline No & Attribute \\
\hline 5 & The founder's vision and mission \\
21 & Company Sustainability \\
13 & Product concept \\
18 & Market Size \\
4 & Charisma of the company leader \\
9 & Company growth \\
\hline 16 & Future projects \\
12 & Appropriate timings \\
13 & Solving problem \\
14 & Revenue / profit \\
10 & Core team \\
20 & Attraction \\
\hline
\end{tabular}

But unfortunately, from 29 indicators there are 11 indicators which according to respondents are of low priority. Indicators or attributes that are a low priority are in quadrant 3 because the importance of the decision of investors to invest is below the average. These attributes can be seen in Table 4.

Table 4 - Attributes that are Low Priorities at Startup XYZ

\begin{tabular}{ll}
\hline No & Attribute \\
\hline 27 & Community sentiment towards the company \\
22 & Company valuation \\
24 & Comments from experts on the media \\
28 & Competitor \\
3 & Corporate responsibility for the environment \\
6 & Work experience / entrepreneurship at the founder \\
8 & The legality of the company \\
17 & Company cash flow \\
26 & The company's decision to follow government regulations \\
19 & Previous investment \\
7 & Number of founders \\
\hline
\end{tabular}

Over-performing. Attributes that are judged to be overperforming but considered less critical by investors according to respondents are in the fourth quadrant as in Table 5.

Table 5 - Attributes whose performance is over-performing at Startup XYZ

\begin{tabular}{cc}
\hline No & Attribute \\
\hline 23 & Exit option \\
\hline
\end{tabular}

Importance-Performance Analysis method applied to identify key performance attributes that play an essential role in customer satisfaction, in this case, is to attract investors to invest in startup $X Y Z$. The research aims to see investors' perceptions of $X Y Z$ based on the Importance-Performance Analysis method.

The researcher uses the 29 indicators from Muzyka et al. (1996) and collaborate with Nunes et al. (2014) and other related journals and input from investors. And it considered as essential and used by investors in evaluating companies.

The result showed that influence investors' perceptions of startup XYZ are indicators whose values are above the average value of 4.2 which are 13 indicators as seen on Table 1. But as seen on Table 2, there are 6 main priorities that must be addressed at startup $X Y Z$. These indicators can influence investors to invest in $X Y Z$.

\section{CONCLUSION}

The study explored there are 13 indicators that influence investors' perceptions of startup $X Y Z$, there are indicators whose values are above the average value of 4,2. XYZ also has 12 indicators that need to be maintained (out of 29 indicators) which indicates that the 
company has been performing at an optimum level. But they have six indicators that need to be addressed as a main priority since it will influence the investors to invest in their startup. However, to get more attraction from investors, $X Y Z$ needs to make better strategy in monetizing their business. Targeting specific customer segment, increasing brand awareness and more innovation in product development can be an option of plan to grow the business.

\section{RECOMMENDATIONS}

Based on the research findings, the startups which looking for investment or a guide to attract the investors to minimize the risk and maximize the funding, can use this method and collaborate with the indicators to check their value to get investors' perceptions. The Importance Performance Analysis method is used to measure the performance of satisfaction that is considered important by the customer and the satisfaction performance received by the customer, and this method is easy to implement, cost-effective, and can easily evaluate the effectiveness of marketing programs.

\section{REFERENCES}

1. Algifari, "Mengukur Kualitas Layanan Dengan Indeks Kepuasan, Metode ImportancePerformance Analysis (IPA), and Model Kano," BPFE-Yogyakarta, Yogyakarta, 2016.

2. Blank, "A Fireside Chat with Steve Blank. Brown University (US)," youtube.com, para. 27, Aug. 2018. [Online]. Available: https://www.youtube.com/watch?time continue $=474 \& v=$ I_OGwrSTWT4. [Accessed: Sept. 25, 2018].

3. Buchari, N.A. Achsani, M. Tambunan, T.N.A. Maulana, "The Capital Structure of Veture Capital Firms in Indonesia," Jurnal Keuangan and Perbangkan, 20(3), pp. 407-416, 1992.

4. C.B. Insights, 'The Top 20 Reasons Startups Fail," cbinsights.com, para. 12, Feb. 2018. [online]. Available: https://www.cbinsights.com/research/startup-failure-reasons-top/. [Accessed: Oct. 23, 2018].

5. N. Chirstanti, L.A. Mahastanti, 'Faktor-faktor yang dipertimbangkan investor dalam melakukan investasi," Jurnal Manajemen Teori and Terapan, 4(3), pp. 37-51, 2011.

6. S. Ghosh, "Why Most Venture-Backed Companies Fail," fastcompany.com, para. 12, Oct. 2012. [Online]. Available: https://www.fastcompany.com/3003827/why-most-venturebacked-companies-fail. [Accessed: Oct. 23, 2018].

7. P. Graham, "Want to start a startup?," paulgraham.com, para. 12, Sep. 2012. [Online]. Available: https://www.paulgraham.com/growth.html. [Accessed: Jul. 9, 2018].

8. T. Goudriian, Startups and Funding, a comparative analysis of Amsterdam and Stockholm, [Tesis], Utrecht University, Netherlands, 2016.

9. Halim, Analisis Investasi, Edisi 2, Salemba Empat, Jakarta. 2005.

10. R.S. Harris, T. Jenkinson, S.N. Kaplan, "Private equity performance: What do we know?," The Journal of Finance, 69(5), pp. 1851-1882. 2014.

11. R.S. Harris, T. Jenkinson, S.N. Kaplan, "How do private equity investments perform compared to public equity?," Journal of Investment Management, 14(3), pp. 1-24. 2016.

12. S.N. Kaplan, J. Lerner, "It Ain;t Broke: The Past, Present, and Future of Venture Capital," Journal of Applied Corporate Finance, 22(2), pp. 36-47, 2010.

13. J.A. Martilla, J.C. James, "Importance Performance Analysis," Journal of Marketing, 41(1), pp. 77 - 79. 1977.

14. M.B. Miles, M.A. Huberman, Qualitative Data Analysis, Sage Publication, London, 1984.

15. D. Muzyka, S. Birley, and B. Leleux, "Trade-offs in the investment decisions of European venture capitalists," Journal of Business Venturing. 11(4), pp. 273-287. 1996.

16. L.S. Muliya, N.S. Imaniyati, Perusahaan modal ventura: dalam perspektif hukum bisnis and hukum islam, [Tesis], Perusahaan modal ventura: dalam perspektif hukum bisnis and hukum Islam, Bandung, 2008. 
17. J.C. Nunes, E.G.S. Felix, C.P Pires, "Which criteria matter most in the evaluation of venture capital investments?," Journal of Small Business and Enterprise Development, 21(3), pp. 505-527, 2014.

18. E. Ries, The Lean Startup: How Today's Entrepreneur Use Continous Innovation to Create Radically Successful Business, Crown Business, New york, 2011.

19. Warner, Paul Graham: The Art of Funding a Startup (A Mixergy Interview), Hiperink and Mixergy, Massachusetts, 2011.

20. C.K. Wong, Critical Success Factors for Limited Service Hotels in Malaysia, [Tesis], University of Nottingham, Nottingham, 2015. 